\title{
SUSTAINABLE TOURISM DEVELOPMENT IN HISTORIC CITIES OF ARID REGIONS WITH THE REVIVAL OF QANAT (YAZD CITY)
}

\author{
Saeedeh MOAYEDFAR ${ }^{*}$ \\ Meybod University, Faculty of Human Sciences, Geography Department, Meybod, Iran, e-mail: moayedfar@meybod.ac.ir \\ Mehran FATEMI \\ Meybod University, Faculty of Human Sciences, Geography Department, Meybod, Iran, e-mail: yazdfatemi@meybod.ac.ir
}

\begin{abstract}
Citation: Moayedfar, S., \& Fatemi, M. (2021). SUSTAINABLE TOURISM DEVELOPMENT IN HISTORIC CITIES OF ARID REGIONS WITH THE REVIVAL OF QANAT (YAZD CITY). GeoJournal of Tourism and Geosites, 35(2), $428-436$. https://doi.org/10.30892/gtg.35222-669
\end{abstract}

\begin{abstract}
Qanat is one of the cultural and geological attractions in arid regions. Iran's Qanat has become the 20th UNESCO World Heritage Site in 2016. Since the Qanat is a cultural, historical, and ecological heritage in addition to its tectonic features, it can include geotourism and, it offers potentials in planning sustainable tourism. Therefore qanat tourism with emphasis sustainable tourism can cause conservation and regeneration of this local capacity. This research has been conducted with the aim of investigating the capabilities of qanats in Yazd from different aspects of tourism. Yazd city was registered as the World heritage city at UNESCO in 2017. According to the hydrologic and tourism experts, the Delphi model has been used, and the SWOT matrix has been formed. According to the AHP model, the results indicate the importance of the strengths and opportunities of the qanat of tourism in this city. The top strategies for tourism boom include investment, the participation of indigenous people, and the creation of museums and Qanatel in qanats.
\end{abstract}

Key words: qanat (aqueduct), sustainable tourism, historical city, Yazd, qanat tourism, desert

$* * * * * *$

\section{INTRODUCTION}

Tourism as an economic phenomenon has economic, social, cultural, personal, and ethical impacts on the hosting communities (Crossley et al., 2012; Othman and Rosli, 2011; Rathore, 2012). Tourism ranks second following the oil industry in its potential in export revenue generation (Othman and Rosli, 2011a; Ghanian et al., 2014). There are two main approaches to tourism planning that are defined about local capacities. In the first approach, tourism is independent of the native culture of each region, which is, in fact, a kind of massive modern tourism that follows a single model all over the world, independent of the geographic areas. The second approach considers tourism as dependent on the native culture, which is known as postmodern tourism, in which the local capacities are systematically involved in the tourism process, and this will ensure the dynamism and maintenance of these spots (Semsar Yazdi and Labbaf Khaneiki, 2014).

In international communities (Quebec Declaration on Ecotourism, 2002) and scientific studies (Bimonte and Punzo, 2003; Ko, 2005; Hashemi and Ghaffary, 2010), sustainable tourism, as a recent approach to tourism, is identified as a means to enhance local developments while protecting their environment, their natural resources, and cultural heritages and values. On the other hand, it means tourism design as a systematic interaction with native elements without damaging destination functions. Sustainable Tourism refers to the ability of the society, the ecosystem and other existing similar systems to operate continuously towards an unanticipated future, while also ensuring that the key resources are not depleted (Joseph et al., 2020). More specifically, water-based tourism around the world is one of the most diverse types of tourism truly representing sustainable tourism indices, which attracts the most number of tourists to bodies of water, such as seas, lakes, rivers, etc and Geotourism preserves the place's identity with the introduction of geomorphological landforms to tourists. However, there are few such tourism resources in desert cities. Qanat has been the source of technological advances in such desert areas in ancient Iran for about three thousand years ago whose main feature is exploiting underground water to the surface of the earth. It is an unique water resource with a high historical and cultural value along with its natural attractions. Since it creates a kind of human ecology, all elements of which have a systematic and sustainable relationship.

In tourism destinations, culture influences management practice. The core element in culture is the value in which the relationship between humans in a society is always influenced by the values that are part of the collective program of people's minds (Waridin and Astawa, 2021). The qanat also has cultural dimensions; because communities are always changing, and they relate to the symbolic dimension of life (Morar et al., 2020). The cultural space of the qanat is even comparable with the cultural places in Petra and Wadi Rum, recorded on the list of the Intangible Cultural Heritage of 2008 (Pineda and Brebbia, 2012). Qanats are considered as ancestral processes which are known under different names in 35 countries around the world. The best known of these are the Qanat in Iran (Goblot, 1963), Khettara in Morocco (Baali et al., 2002), Falj in Sultanate of Oman, and the Karez in Afghanistan (Hussain et al., 2008; Remini et al., 2014).

\footnotetext{
* Corresponding author
} 
The qanat of concern in tourism is a place whose geographic location and structural and non-structural features are suitable for attracting tourists. In fact, touristic potentials of qanat are not at least less than the aqueducts, rivers, and other sources of water, but other water resources have gained a much better position in the tourism sector. The potential of this type of tourism can be more in the field of heritage and nostalgia (Papoli Yazdi and Labbaf Khaneiki, 2000), which are one of the main components of postmodern tourism and could be considered as the symbol of a society's traditional culture in the past. Qanat tourism can be used in the category of cultural tourism. Most tourists in Yazd are cultural tourists whose main purpose is to visit the historical and cultural monuments of this city (Makiyan and Naderi, 2003).

Therefore, qanat as a new attraction in the post-modern age can help the tourism sector in Iran and particularly in Yazd, as a desert city in Iran, which was added to UNESCO's World Heritage List as UNESCO World Heritage Site in 2017. The social and civil evolution is deeply indebted to qanats, so urban tourism and qanat tourism are interwoven in this city. However, unfortunately, the use of qanats in the tourism sector of Yazd has not been much used so far. That is why the researcher in this study considers tourism as a feasible way to get qanats in Yazd more visible and more respected as a cultural heritage remained through centuries of human endeavors. Since tourists around the world are now seeking to visit places that are less visible or even unknown, and especially desert tourism is a priority for many of them, it seems that visiting the aqueduct, its structure, and function, an attractive destination for many tourists, especially geotourists and ecotourists.

Although qanat theme has attracted attention from academics and researchers in various sciences, this has been less noticeable in tourism. Mehrvaran (2005), for instance, has examined the impacts of the development of Shiraz city on the quantity and quality of Kooshk qanat water, who believes both the amount of water and its quality have changed during the development process. Another researcher (Sadeghirad, 2005) has tried to provide solutions with using the MODFLOW model and the qanat system structure for better use of groundwater in the Shiraz plain.

Nasiriyen (2006) has examined the factors affecting the sustainable development of irrigation system about the qanat system and believes that reforming the irrigation system can play an important role in the development and promotion of agriculture. In addition, Mustafa and Usman (2007) argued about irrigation changes from the traditional way to pumping of groundwater by tube wells that this problem can cause besides affecting environmental quality to an erosion of social capital and the loss of equity in rural regions. In another study by Hussain et al. (2008) provide a review of the global literature on the status and potential of karezes and presents case studies for Afghanistan, Iran, Pakistan, and Kingdom of Saudi Arabia (Figure 1). It offers syntheses of guide issues, lessons, options and proposed interventions for re-vitalizing the karez systems. The paper identifies criteria for prioritizing karez systems for rehabilitation and outlines significant conditions for their effective functioning and sustainability. Furthermore, Laghaei et al. (2012) by measuring all the qualitative variables of water in SangLage qanat of Tehran, the pollution of this water and other threatening factors have been revealed to them. Accordingly, strategies for the restoration and revitalization of this qanat have been presented as a sample for sustainable water management and the use of qanat capacities in the urban fabric. For instance, Abbasnejad et al. (2016) examine the hazards of qanats in the urban areas due to the structure of qanats (Figure 2), and they believe this problem can be considered as a specific type of geologic danger and have explained the causes, effects, and solutions to contrast this danger.

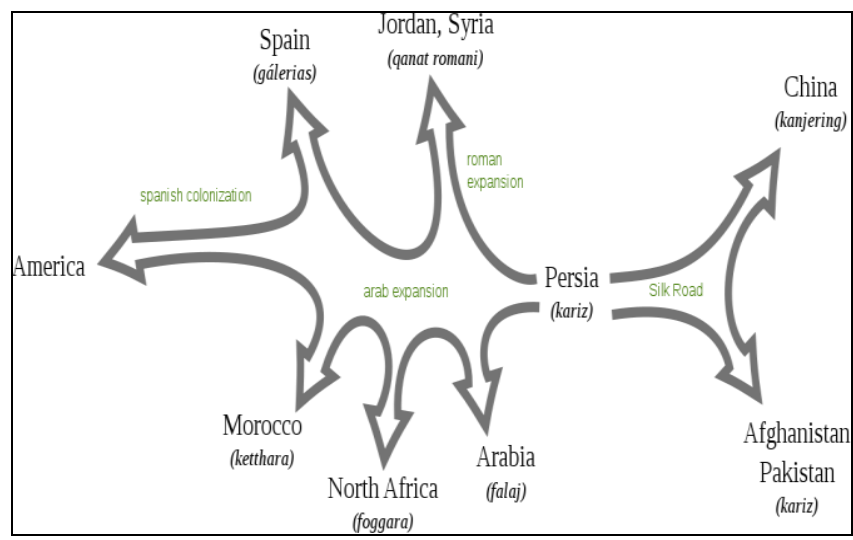

Figure 1. Probable diffusion and names of qanat technology (source:Vaughan, 2021)

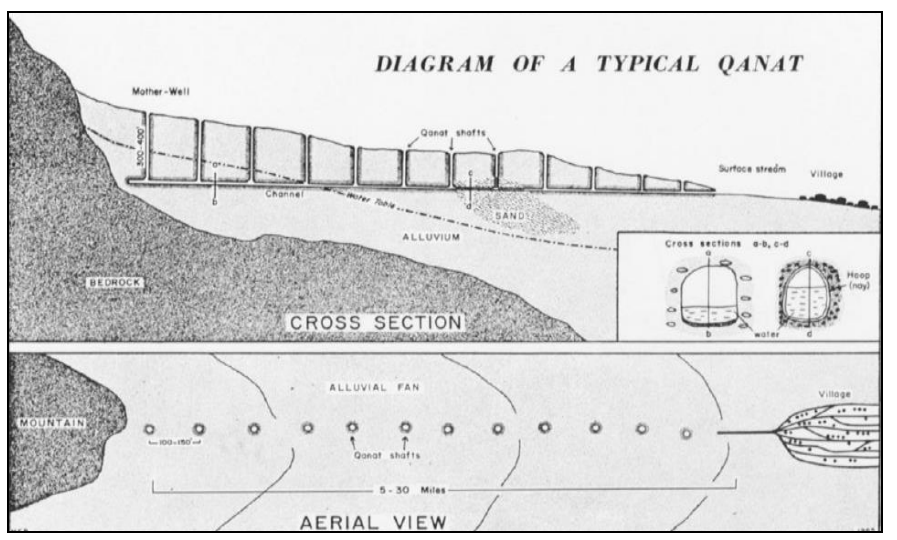

Figure 2. Diagram of a typical qanat (source: English, 1968)

According to Parise (2016)'s study, has made comments on the previous article and believes that qanat is not a geologic hazard, but qanat systems have the remarkable importance on the development of similar underground structures in many countries of the Mediterranean Basin, which this remarks the relevance of qanat as cultural heritage sites and the need for their preservation and valorization. Moreover, Goes (2017) has discussed the issue of the Afghanistan qanats in his article and has proposed strategies for the reconstruction of the qanats. He believes that although this is not economically feasible compared to digging deep wells, the qanats need special attention as a legacy for Afghanistan solidarity. Based on the above, several studies have explored various aspects of qanat for structure, water quality, hazards and it's capabilities, but limited research focused on the capacities qanat for tourism. In contrast, this paper focuses on the tourism aspects of the qanat and is attempting to present a sustainable tourism pattern in this regard. As a result, this study aims at providing an answer to the question of what potentials the qanats have in the city of Yazd and how these potentials can be deployed in the tourism sector and how can we achieve the sustainable development of tourism in Yazd by restoring the qanat tourism? 


\section{RESEARCH FRAMEWORK}

A qanat is a gently sloping underground channel to transport water from an aquifer or water well to surface for irrigation and drinking, or an old system of water supply from a deep well with a series of vertical access shafts. The qanats still create a reliable supply of water for human settlements and irrigation in hot, arid, and semi-arid climates. The qanat technology was developed in ancient Iran by the Persian people sometime in the early 1st millennium BC, and spread from there slowly westward and eastward (Wilson, 2008). The qanat consists of the main components and dependent elements. The main parts includes the mother well, access shaft, qanat channel, and outlet. Figure 2 shows how the distribution of qanat water in a wide geographical range and its systematic linkages with elements of urban and rural life. On the other hand, these elements can be considered in the form of tangible and intangible values of a cultural and tourism attraction. Tangible values derive from the structural and physical characteristics of a space that they have historically, culturally or technically important or are unique. In contrast, intangible values are conceptual and nonstructural features that are rooted in social, economic, political, historical and artistic processes (Gravili et al., 2015). Human interaction involves the environment and society, and they do not have an outer shape. For example, the channel of the qanat is considered to be tangible, but indigenous knowledge is considered intangible for its maintenance. As a result, intangible values make up an important part of the tourist attractions, and tourists are searching for many of these values around the world (Semsar Yazdi and Labbaf Khaneiki, 2014a).

According to the expectations and interests of tourists, it is possible to divide the attractions of the qanat into five sections (Carrión and Fornes, 2016):

-Natural attractions: At the bottom of the qanat, the accumulation of calcium carbonate around the roots of the trees creates beautiful scenery that attracts everyone interested to nature. Also, due to the presence of some aquatic animal species, such as fish, crabs and shrimp in the qanat, this structure is more attractive to tourists.

-Cultural attractions: Recreating some of the ancient ceremonies that were held near the qanats in the past, like the marriage of Qanats and rain reading can attract tourists interested in the culture of civilizations. Other cultural attractions include water clocks and a means to measure the flow of water.

-Adventurous attractions: Landing in the qanat well, walking in the qanat gallery and the complex geometry of the qanats' interior can be an expression of geotourism.

-Technical Attractions: How to dig in the past with basic facilities, accurate calculations, regular routing, shaft-wells and tunnel bars, are the technical tips of the qanats that many people are looking for.

- Social Attractions: Access to qanat has been based on the social level of families in the past. In the sense that, higher-income families have access to water at the upper qanat, and families with lower levels have less chance of accessing water. This is important for those interested in sociology. Also, how to qanat managing and its water distribution is significant for tourism.

According to the above, it can be said that all the qanats in the world do not have the necessary characteristics to become a tourist destination. Tourism qanat should not only be appropriate regarding geographic location and structure for attracting tourists but also should be able to accommodate tourists. In such a way that the function of the qanats is not disturbed, and it will be profitable for the qanat.

\section{THE LOCATION OF THE STUDIED AREA}

The City of Yazd is located in the middle of the Iranian plateau, $270 \mathrm{~km}$ southeast of Isfahan (Safarabadi et al., 2015), close to the Spice and Silk Roads. It bears living testimony to the use of limited resources for survival in the desert. Water is supplied to the city through a qanat system developed to draw underground water. The earthen architecture of Yazd has escaped the modernization that destroyed many traditional earthen towns, retaining its traditional districts, the qanat system, traditional houses, Bazars, Hammams, Mosques, Synagogues, Zoroastrian temples and the historic garden of Dolat-Abad (UNESCO, 2017). This city has become the country's 22nd world heritage site after the World Heritage Committee voted in favor of it's in 2017. Yazd is now the only UNESCO-listed Iranian city where people still live (Figure 3).

Due to its dry climate, Yazd has been considered as one of the world's largest qanat centers since the past. The technology of the qanat is unique in this land and has been derived from the past generations. In Yazd, the most important elements related to the aqueduct include market, indigenous architecture, temples, agriculture, and urban gardening and the spatial arrangement of neighborhoods. Traditional markets and the orientation of historic neighborhoods largely follow the status of the source of water access. So Bunin considers the network of qanats as the main reason for the configuration of the Yazd city pattern (Bonine, 1979). Architectural interaction with the qanats is also two-sided, which means that on the one hand the qanat has come to the aid of architecture and has given new functions to it, and on the other hand, the structures associated with the qanat enjoy the same native architectural techniques. The manifestation of the aqueduct in the structure of the old houses is also well seen in the spring house, Payab and Basement.

Also, qanat and religious architecture have a long history. Water is considered one of the four holy elements of nature, and it has a high status in Zoroastrianism, so that water is supplied to the fire temples through the qanats, and this tradition has led to mosques in the city through Iranian culture. So that water is in the center of mosques and plays an important role in the prayers. Therefore, the qanats flowed like the body's arteries in the city of Yazd, and the movement of the qanat route made it possible for the tourists to visit several other monuments and bring him to the center of the old neighborhoods. In the past, there were over 70 qanats running beneath the city, and now there are at least 8 active Qatats in the urban vicinity, including the qanat of Qasem Abad, Qasem Naqi, Rahmat Abad, Hassan Abad, Zarch, Najaf Abad, Kheyr Abad, and Shehneh. It should be noted that the Zarch Qanat is the longest Iranian qanat with a length of more than 70 kilometers. Iran has had successful experiences in exploiting qanats for tourism purposes, for example, the underground city of Kish Island and the Mahan Arg in Kerman. 
Considering the abilities of the qanats of Yazd, sure planning for them can certainly affect the city's tourism prosperity. Indeed, with the emphasis on the capacities of the Yazd city qanats, the strategic planning can be useful in boosting tourism.
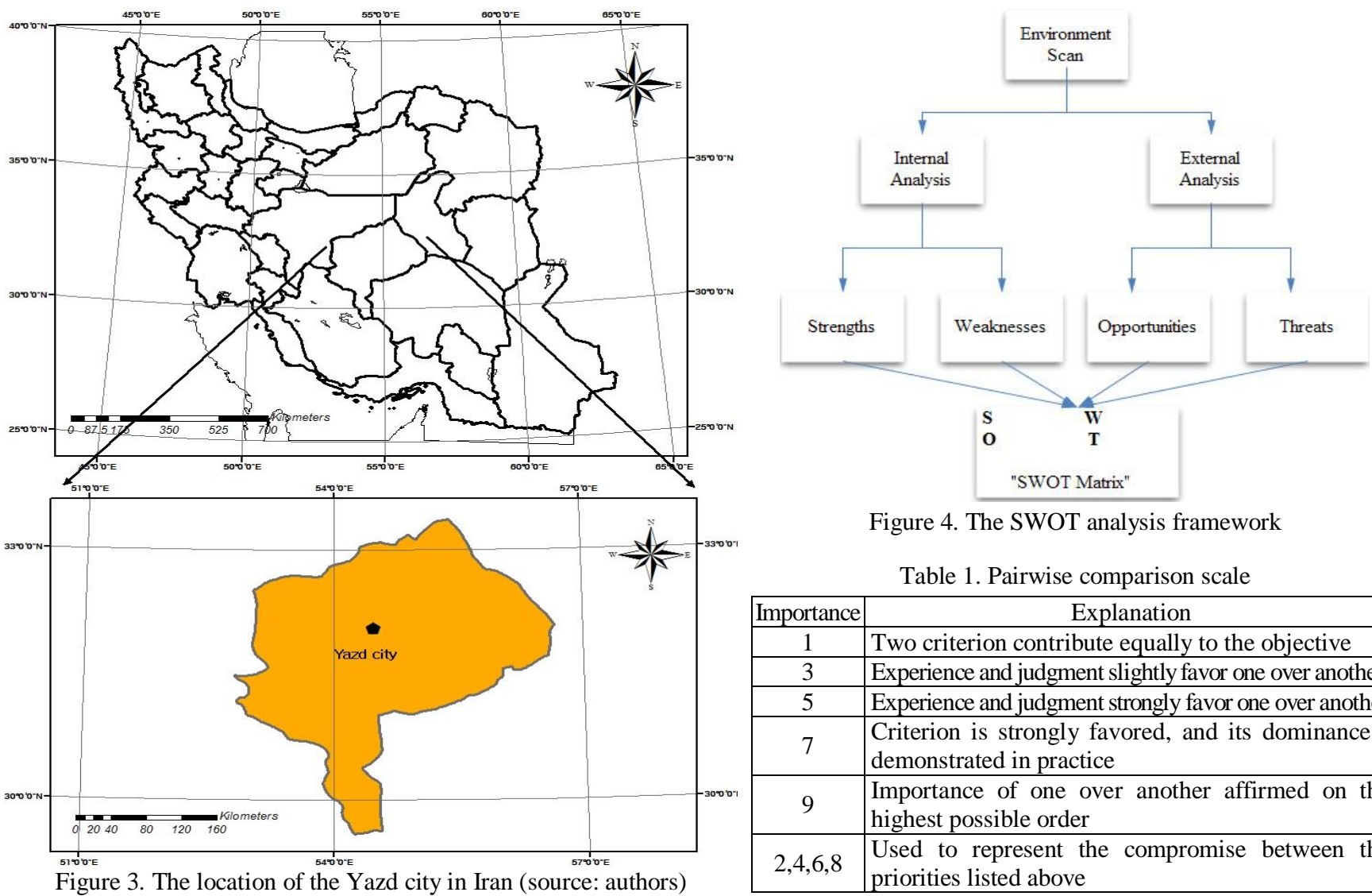

Figure 4. The SWOT analysis framework

Table 1. Pairwise comparison scale

\begin{tabular}{|c|l|}
\hline Importance & \multicolumn{1}{|c|}{ Explanation } \\
\hline 1 & Two criterion contribute equally to the objective \\
\hline 3 & Experience and judgment slightly favor one over another \\
\hline 5 & Experience and judgment strongly favor one over another \\
\hline 7 & $\begin{array}{l}\text { Criterion is strongly favored, and its dominance is } \\
\text { demonstrated in practice }\end{array}$ \\
\hline 9 & $\begin{array}{l}\text { Importance of one over another affirmed on the } \\
\text { highest possible order }\end{array}$ \\
\hline $2,4,6,8$ & $\begin{array}{l}\text { Used to represent the compromise between the } \\
\text { priorities listed above }\end{array}$ \\
\hline
\end{tabular}

\section{MATERIALS AND METHODS}

The approach of this research is descriptive-analytic. To collect the required data, library and field studies are used, and according to the obtained data, the general status of the qanat tourism in Yazd city has been investigated. The technique used in this research is Delphi. Delphi participants are experts. They have four characteristics: knowledge and experience in the subject, the willingness, the time of cooperation and effective communication skills (Rowe and Wright, 1999). In the majority of cases, sampling is based on the purpose, but if experts are not identified, snowball sampling is also used. If experts are wellknown and large, random sampling is used. The number of participants is usually less than 50 people and mostly 15 to 20 people.

Accordingly, in this research, among the experts in the cultural heritage of Yazd Considering the purpose of the research and the specification presented, non-random sampling was used and the sample number was 15, of which men were 40-50 years old and had a 15-year experience in tourism and qanat in Yazd. Next, according to the Delphi method, the views of experts on qanat tourism and its capabilities for Yazd city were examined. In the second stage, based on these views and SWOT analysis With the purpose of developing the qanat tourism in the Yazd city, the strengths, weaknesses, opportunities, and threats of this type of tourism were extracted. The SWOT compiles the most important results from the analysis of external drivers and the internal analysis competences of an organization. The objective of the SWOT is to determine to what degree the actual strategy is suitable and appropriate to meet the challenges and changes in the organization,s environment. Figure 4 shows how SWOT analysis fits into an environment scan (Kahraman et al., 2008).

In the next step, the $\mathrm{AHP}^{1}$ model was used, which was the reason for using it to compare the paired strengths, weaknesses, opportunities and threats by the relevant experts. The prioritization mechanism is accomplished by assigning a number from a comparison scale (Table 1) developed by Saaty (1980) to represent the relative importance of the criteria. Pairwise comparisons matrices of these factors provide the means for calculation of importance (Sharma et al., 2008).

In typical SWOT analysis, the weightiness of the factors is not quantified to determine the effect of each factor on the proposed strategy alternatives (Yuksel and Dagdeviren, 2007). SWOT analysis does not provide a means of systematically determining the relative importance of the criteria or to assess decision alternatives according to these criteria. To handle this insufficiency, the SWOT framework is converted into a hierarchic structure, and the model is integrated and analyzed using the AHP with its eigenvalue calculation method (Gorener et al., 2012). In this study, the AHP structure results from the SWOT matrix and is separated in three parts: (a) goal to be achieved by the decision, (b) the SWOT groups and (c) the factors included within each SWOT group (sub-criteria). The hierarchical representation of the SWOT structure is shown in Figure 5.

Finally, the process of the theoretical framework of the research can be presented in Figure 6.

1. AHP is a multicriteria decision-making technique that can help express the general decision operation by decomposing a complicated problem into a multilevel hierarchical structure of objective, criteria, and alternatives (Sharma et al., 2008). AHP performs pairwise comparisons to derive relative importance of the variable in each level of the hierarchy and/or appraises the alternatives in the lowest level of the hierarchy to make the best decision among alternatives. 


\section{RESULTS DISCUSSIONS}

As explained before, the research data is provided in a few steps through the questionnaire. The results of the first stage which are made up of open questions about the qanat and its capabilities, as well as its limitations and problems in the field of tourism. This process is done by Delphi technique and 15 expert comments.

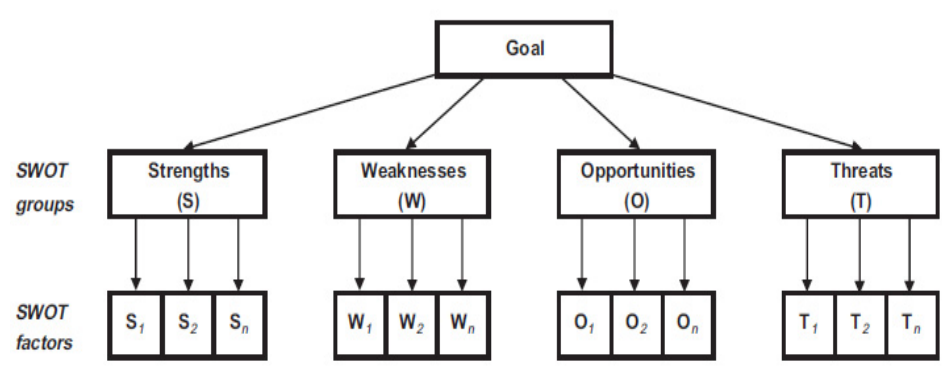

Figure 5. The hierarchical structure of the SWOT matrix

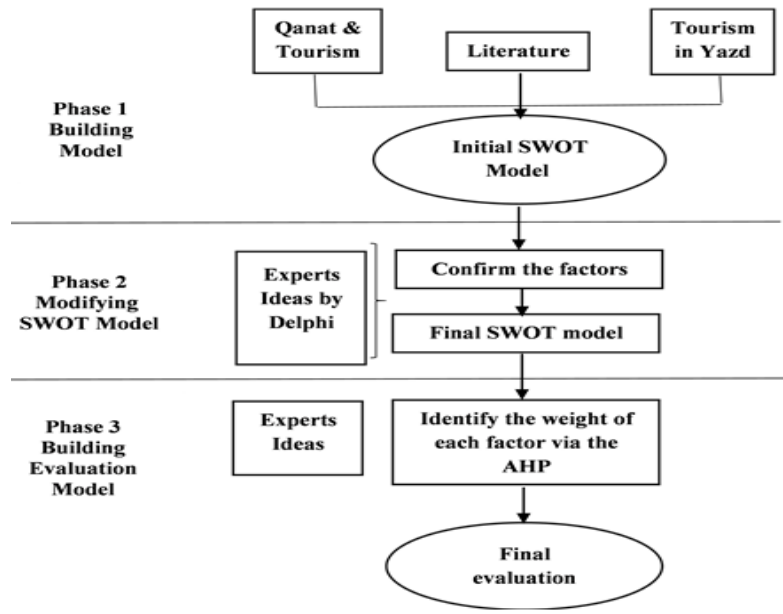

Figure 6. Phases of the proposed methodology (source: authors)

In the second step, by receiving these questionnaires, we tried to identify the strengths, weaknesses, opportunities, and threats and return them to the experts to identify the most wanted items in SWOT matrix. According to the relative frequency of each parameter, were identified as final strengths, weaknesses, opportunities, and threats. Table 2 shows the SWOT matrix.

Table 2. The SWOT matrix about qanat tourism

\begin{tabular}{|c|c|}
\hline Str & $\mathrm{W}$ \\
\hline $\begin{array}{l}\text { 1) The unique technology of the aqueduct } \\
\text { 2) Ecotourism and Geotourism attractions } \\
\text { 3) The structural and functional significance } \\
\text { 4) Appropriate cultural perspective in the form of Zoroastrian and } \\
\text { uslim interaction in Yazd to exploit aqueducts in agriculture } \\
\text { 15)The systematic connection of Qanat with other historical attractions } \\
\text { 6) Easy access to the aqueduct and convenient access to its various parts } \\
\text { 7) The long civilization of the qanat } \\
\text { 8) Using the landscape of the desert in the manifestation of the qanat } \\
\text { d the catacombs' landscape in the manifestation of the Yazd qanats }\end{array}$ & $\begin{array}{l}\text { (W1) The proximity of the qanat to the Yazd city is problematic for } \\
\text { technical reasons } \\
\text { (W2) Uncertain route of the qanats in some parts of the city } \\
\text { (W3) The destructive structural changes in the aqueduct as a result } \\
\text { of unbridled excavations and the destruction of the authenticity of } \\
\text { the qanat } \\
\text { (W4) Impact of climate change and recent droughts on Yazd qanats } \\
\text { (W5) Management weakness in the rehabilitation of qanats and } \\
\text { connecting this civilization attraction to other places of Yazd } \\
\text { (W6) The neglect of investing in Yazd qanats with the approach of tourism }\end{array}$ \\
\hline Oppor & Threats (T) \\
\hline $\begin{array}{l}\text { (O1) Register Yazd city in the list of world heritage cities in } \\
\text { UNESCO } \\
\text { (O2) The first rank of Yazd qanats in Iran } \\
\text { (O3) Historic, cultural and archeological attractions of the qanat for } \\
\text { tourists } \\
\text { (O4) Special Geomorphology Attractions of Yazd qanats } \\
\text { (O5) Located in the cultural cycle of Iran (Isfahan-Shiraz-Yazd) } \\
\text { (O6) Formation of the urban's structure and its expansion based on } \\
\text { the qanat network } \\
\text { (O7) Less damage to the environment and sustainable tourism } \\
\text { (O8) The emphasis of international conventions on the preservation } \\
\text { of native technology and knowledge }\end{array}$ & $\begin{array}{l}\text { (T1) Unauthorized withdrawal of water from the aqueduct for water } \\
\text { supply in various projects, especially tourism } \\
\text { (T2) Contamination in the aqueduct } \\
\text { (T3) Reducing people's participation in the maintenance and } \\
\text { restoration of qanats } \\
\text { (T4) The increase in land prices and the change in the use of } \\
\text { agricultural land and the removal of aqueducts } \\
\text { (T5) Lack of welcome to foreign tourists due to negative promotions } \\
\text { (T6) The occurrence of landslide crisis in various cities of Iran and } \\
\text { the creation of a crisis in tourism } \\
\text { (T7) Lack of awareness of the visit of the aqueducts by tourists } \\
\text { (T8) Lack of qanat rules and regulations for the maintenance of the aqueducts }\end{array}$ \\
\hline
\end{tabular}

Next, AHP is applied to the SWOT matrix. Firstly, pairwise comparisons of the SWOT groups, using a 1-9 Saaty s (1980) comparison scale, are made. The comparison results are shown in Table 3. Secondly, SWOT matrices elements are compared considering every SWOT group (Table 4, Table 5, Table 6, Table 7). All pairwise comparisons in the application are performed by the team of experts (15 people). The expert team was constituted from two department managers of the tourism and the water resources.

Table 3. Pairwise comparisons of SWOT factors

\begin{tabular}{|l|c|c|c|c|c|}
\hline SWOT Groups & $\mathrm{S}$ & $\mathrm{W}$ & $\mathrm{O}$ & $\mathrm{T}$ & Importance Degrees of SWOT Groups \\
\hline Strengths (S) & 1 & 3 & 1 & 3 & 0.366 \\
\hline Weaknesses (W) & 0.33 & 1 & 0.25 & 2 & 0.143 \\
\hline Opportunities (O) & 1 & 4 & 1 & 2 & 0.371 \\
\hline Threats (T) & 0.33 & 0.5 & 0.5 & 1 & 0.120 \\
\hline $\mathrm{CR}=0.06$ & & & & & \\
\hline
\end{tabular}


Table 4. Comparison Matrix of Strengths Group

\begin{tabular}{|c|c|c|c|c|c|c|c|c|c|}
\hline Strengths & S1 & S2 & S3 & S4 & S5 & S6 & S7 & S8 & $\begin{array}{l}\text { Importance } \\
\text { Degree }\end{array}$ \\
\hline (S1) The unique technology of the aqueduct & 1 & 2 & 0.2 & 0.25 & 0.25 & 0.5 & 1 & 0.25 & 0.05 \\
\hline (S2) Ecotouristic and Geotouristic attractions & 0.5 & 1 & 1 & 0.33 & 0.5 & 0.2 & 0.5 & 0.33 & 0.059 \\
\hline (S3) The structural and functional significance & 0.5 & 1 & 1 & 3 & 1 & 4 & 2 & 0.5 & 0.203 \\
\hline $\begin{array}{l}\text { (S4) Appropriate cultural perspective in the form of Zoroastrian and Muslim } \\
\text { interaction in Yazd to exploit aqueducts in agriculture }\end{array}$ & 4 & 3 & 0.33 & 1 & 2 & 2 & 4 & 1 & 0.17 \\
\hline (S5)The systematic connection of Qanat with other historical attractions & 4 & 2 & 1 & 0.5 & 1 & 1 & 2 & 0.5 & 0.118 \\
\hline (S6) Easy access to the aqueduct and convenient access to its various parts & 2 & 5 & 0.25 & 0.5 & 1 & 1 & 4 & 0.33 & 0.118 \\
\hline (S7) The long civilization of the qanat & 1 & 2 & 0.5 & 0.25 & 0.5 & 0.25 & 1 & 0.2 & 0.055 \\
\hline $\begin{array}{l}\text { (S8) Using the landscape of the desert in the manifestation of the Qanat and the } \\
\text { catacombs' landscape in the manifestation of the Yazd Qanats }\end{array}$ & 4 & 3 & 2 & 1 & 2 & 3 & 5 & 1 & 0.227 \\
\hline $\mathrm{CR}=0.1$ & & & & & & & & & \\
\hline
\end{tabular}

Table 5. Comparison Matrix of Weaknesses Group

\begin{tabular}{|c|c|c|c|c|c|c|c|}
\hline Weaknesses 1 & W1 & W2 & W3 & W4 & W5 & W6 & $\begin{array}{l}\text { Importance } \\
\text { Degree }\end{array}$ \\
\hline (W1) The proximity of the qanat to the Yazd city is problematic for technical reasons & 1 & 1 & 0.2 & 0.25 & 0.17 & 0.14 & 0.037 \\
\hline (W2) Uncertain route of the Qanats in some parts of the city & 1 & 1 & 0.25 & 0.2 & 0.25 & 0.17 & 0.042 \\
\hline $\begin{array}{l}\text { (W3) The destructive structural changes in the aqueduct as a result of unbridled } \\
\text { excavations and the destruction of the authenticity of the aqueduct }\end{array}$ & 5 & 4 & 1 & 3 & 0.33 & 0.25 & 0.158 \\
\hline (W4) Impact of climate change and recent droughts on Yazd aqueducts & 4 & 5 & 0.33 & 1 & 0.33 & 0.2 & 0.106 \\
\hline $\begin{array}{l}\text { (W5) Management weakness in the rehabilitation of Qnats and connecting this } \\
\text { civilization attraction to other places of Yazd }\end{array}$ & 6 & 4 & 3 & 3 & 1 & 0.5 & 0.255 \\
\hline (W6) The neglect of investing in Yazd Qanats with the approach of tourism & 7 & 6 & 4 & 5 & 2 & 1 & 0.402 \\
\hline $\mathrm{CR}=0.07$ & & & & & & & \\
\hline
\end{tabular}

Table 6. Comparison Matrix of Opportunities Group

\begin{tabular}{|l|c|c|c|c|c|c|c|c|c|}
\hline \multicolumn{1}{|c|}{ Opportunities } & O1 & O2 & O3 & O4 & O5 & O6 & O7 & O8 & $\begin{array}{c}\text { Importance } \\
\text { Degree }\end{array}$ \\
\hline (O1) Register Yazd city in the list of world heritage cities in UNESCO & 1 & 7 & 3 & 3 & 1 & 5 & 1 & 1 & 0.18 \\
\hline (O2) The first rank of Yazd Qanats in Iran & 0.14 & 1 & 0.25 & 0.2 & 0.25 & 0.5 & 0.14 & 0.17 & 0.024 \\
\hline (O3) Historic, cultural and archeological attractions of the Qanat for tourists & 0.33 & 4 & 1 & 0.5 & 0.33 & 4 & 0.2 & 0.2 & 0.061 \\
\hline (O4) Special Geomorphology Attractions of Yazd Aqueducts & 0.33 & 5 & 2 & 1 & 0.33 & 2 & 0.5 & 0.25 & 0.078 \\
\hline (O5) Located in the cultural cycle of Iran (Isfahan-Shiraz-Yazd) & 1 & 4 & 3 & 3 & 1 & 4 & 0.25 & 0.25 & 0.125 \\
\hline (O6) Formation of the urban's structure and its expansion based on the qanat network & 0.2 & 2 & 0.25 & 0.5 & 0.25 & 1 & 0.14 & 0.125 & 0.031 \\
\hline $\begin{array}{l}\text { (O7) Less damage to the environment and sustainable tourism } \\
\text { (O8) The emphasis of international conventions on the preservation of native } \\
\text { technology and knowledge }\end{array}$ & 1 & 7 & 5 & 2 & 4 & 7 & 1 & 0.5 & 0.22 \\
\hline \multicolumn{1}{|c|}{ CR=0.06 } & 6 & 5 & 4 & 4 & 8 & 7 & 1 & 0.28 \\
\hline
\end{tabular}

Table 7. Comparison Matrix of Threats Group

\begin{tabular}{|l|c|c|c|c|c|c|c|c|c|}
\hline \multicolumn{1}{|c|}{ Threats } & T1 & T2 & T3 & T4 & T5 & T6 & T7 & T8 Importance \\
Degree
\end{tabular}

Finally, the overall priority scores of the SWOT factors are calculated. Overall priorities are shown in Table 8.

According to the results of the table, the main strengths and weaknesses of the qanat tourism in Yazd city are S8=0.083, $\mathrm{S} 3=0.0742, \mathrm{~S} 4=0.622$ and $\mathrm{W} 6=0.057, \mathrm{~W} 5=0.0364$. In assessing the external environment, identification the opportunities and threats facing qanat tourism, the most important opportunities and threats consider $\mathrm{O} 1=0.0667, \mathrm{O} 5=0.0463$ and $\mathrm{T} 5=0.027$, $\mathrm{T} 7=0.0267$. In the next step, we can propose the most important strategies of the identified factors, which are (Table 9):

SO Strategies (Maxi-Maxi) or Strategy of differentiated approach that provides marketing mix differently than competitive destinations (including S1/S2/S4/O3/O2). 
WO Strategies (Mini- Maxi) or Strategy of shareholder involvement in tourism development that involvement of shareholders in decision-making, improve product quality and concern for consumers (including W2/W3/W4/W5/W6/O8/O2).

Table 8. Overall Priority Scores of SWOT Factors

\begin{tabular}{|c|c|c|c|c|}
\hline $\begin{array}{c}\text { Swot } \\
\text { Group }\end{array}$ & \begin{tabular}{|c|} 
Group \\
Priority
\end{tabular} & Swot Factors & \begin{tabular}{|c|} 
Factor Priority \\
within the Group
\end{tabular} & $\begin{array}{l}\text { Overall Priority } \\
\text { Of Factor }\end{array}$ \\
\hline \multirow{8}{*}{ 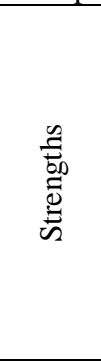 } & \multirow{8}{*}{0.366} & (S1) The unique technology of the aqueduct & 0.05 & 0.018 \\
\hline & & (S2) Ecotouristic and Geotouristic attractions & 0.06 & 0.021 \\
\hline & & (S3) The structural and functional significance & 0.20 & 0.074 \\
\hline & & $\begin{array}{l}\text { (S4) Appropriate cultural perspective in the form of Zoroastrian and Muslim interaction } \\
\text { in Yazd to exploit aqueducts in agriculture }\end{array}$ & 0.17 & .062 \\
\hline & & (S5)The systematic connection of qanat with other historical attractions & 0.12 & 0.043 \\
\hline & & (S6) Easy access to the aqueduct and convenient access to its various parts & 0.12 & 0.043 \\
\hline & & (S7) The long civilization of the qanat & 0.05 & 0.02 \\
\hline & & $\begin{array}{l}\text { (S8) Using the landscape of the desert in the manifestation of the qanat and the } \\
\text { catacombs' landscape in the manifestation of the Yazd qanats }\end{array}$ & 0.23 & 0.083 \\
\hline \multirow{6}{*}{ 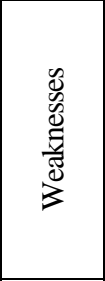 } & \multirow{6}{*}{0.143} & (W1) The proximity of the qanat to the Yazd city is problematic for technical reasons & 0.04 & 0.005 \\
\hline & & (W2) Uncertain route of the Qanats in some parts of the city & 0.04 & 0.006 \\
\hline & & $\begin{array}{l}\text { (W3) The destructive structural changes in the aqueduct as a result of unbridled } \\
\text { excavations and the destruction of the authenticity of the aqueduct }\end{array}$ & 0.16 & 0.022 \\
\hline & & (W4) Impact of climate change and recent droughts on Yazd aqueducts & 0.11 & 0.015 \\
\hline & & $\begin{array}{l}\text { W5) Management weakness in the rehabilitation of qanats and connecting this } \\
\text { civilization attraction to other places of Yazd }\end{array}$ & 0.25 & 0.036 \\
\hline & & (W6) The neglect of investing in Yazd qanats with the approach of tourism & 0.40 & 0.057 \\
\hline \multirow{8}{*}{ 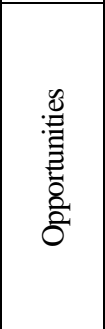 } & \multirow{8}{*}{0.371} & (O1) Register Yazd city in the list of world heritage cities in UNESCO & 0.18 & 0.067 \\
\hline & & $(\mathrm{O} 2)$ The first rank of Yazd qanats in Iran & 0.02 & 0.009 \\
\hline & & (O3) Historical, cultural and archeological attractions of the qanat for tourists & 0.06 & 0.023 \\
\hline & & (O4) Special Geomorphology Attractions of Yazd Aqueducts & 0.08 & 0.029 \\
\hline & & (O5) Located in the cultural cycle of Iran (Isfahan-Shiraz-Yazd) & 0.12 & 0.046 \\
\hline & & (O6) Formation of the urban's structure and its expansion based on the qanat network & 0.03 & 0.011 \\
\hline & & (O7) Less damage to the environment and sustainable tourism & 0.22 & 0.082 \\
\hline & & $\begin{array}{l}\text { (O8) The emphasis of international conventions on the preservation of native technology } \\
\text { and knowledge }\end{array}$ & 0.28 & 0.104 \\
\hline \multirow{8}{*}{$\begin{array}{l}\stackrel{\mathscr{E}}{\mathbb{E}} \\
\stackrel{\Xi}{E}\end{array}$} & \multirow{8}{*}{0.120} & $\begin{array}{l}\text { (T1) Unauthorized withdrawal of water from the aqueduct for water supply in various } \\
\text { projects, especially tourism }\end{array}$ & 0.05 & 0.006 \\
\hline & & (T2) Contamination in the aqueduct & 0.03 & 0.004 \\
\hline & & (T3) Reducing people's participation in the maintenance and restoration of aqueducts & 0.04 & 0.008 \\
\hline & & $\begin{array}{l}\text { T4) The increase in land prices and the change in the use of agricultural land and the } \\
\text { removal of aqueducts }\end{array}$ & 0.07 & 0.008 \\
\hline & & (T5) Lack of welcome to foreign tourists due to negative promotions & 0.22 & 0.027 \\
\hline & & $\begin{array}{l}\text { (T6) The occurrence of landslide crisis in various cities of Iran and the creation of a } \\
\text { crisis in tourism }\end{array}$ & 0.17 & 0.021 \\
\hline & & (T7) Lack of awareness of the visit of the aqueducts by tourists & 0.22 & 0.027 \\
\hline & & (T8) Lack of adequate rules and regulations for the maintenance of the aqueducts & 0.19 & 0.023 \\
\hline $\begin{array}{c}\text { Overal } \\
\text { sum }\end{array}$ & & & & 1 \\
\hline
\end{tabular}

- The strategy of diversification of distribution channels: distribution channels have the power to influence it, "when," "where" and "how" people are traveling, and so to some extent, control how many people come to a destination (includes W3/W2/W5/W1 / O3/O2/O1/O3).

ST Strategies (Maxi-Mini) or Segmented marketing strategy with product modification: Segmentation identifies specific categories of homogeneous preferences among tourists (includes S1/S2/S4/S3/T2/T1).

- Proactive communication strategy: prevent the potential negative image in the minds of visitors, must be centralized, honest, transparent and informative (S1/S2/T2).

WT Strategies: Mini-Mini

- Launch efficient/ flexible marketing promotional strategies: creating confidence in the target market: special events, billboards, trade shows, TV programs, public relations, advertising are the best tactics for promotion (W3/T2/T1).

- Organizational interrelationships and work team: tourism is a set of variety services which include many parties. Therefore it is necessary to develop a network among them (W2/W1/W3/T2/T1).

At the first, the process of selecting the best strategy for qanat tourism planning based on the weighting of the four factors of SWOT concluding the weighting factor of the factors $\mathrm{S}=0.366, \mathrm{~W}=0.143, \mathrm{O}=0.371, \mathrm{~T}=0.120$ (Figure 7 ). Accordingly, opportunities get the highest points and then in order strengths, weaknesses and Threats. In the next step, to rank the strategies concerning the combined strategies, the points of the factors will be added together that $\mathrm{SO}=0.733$, $\mathrm{WO}=0.514, \mathrm{ST}=0.486, \mathrm{WT}=0.263$ (Figure 8 ).

Based on this, the SO strategies regarding the development of qanat tourism in Yazd could include:

- Private sector investment for qanats with tourism capacity in Yazd (Currently, private sector investment is limited to urban areas and traditional homes, and other types of tourism like qanat are unknown) 
- Preparation of plans for the development of cultural tourism, especially qanat, for the development of various types of tourism such as urban tourism, ecotourism and geo-tourism (Major existing plans are a comprehensive urban plan, and there is no comprehensive tourism plan)

- Expansion of facilities for tourists (hotels, restaurants, dining rooms) near the main qanats of Yazd and qanatel (hotel in qanat)

- Creating a museum in qanats to provide tools related to this technology and showing its different parts

- Creating the right ads on the introduction of tourist attractions in the historic city of Yazd, especially the city's qanat

- Exploitation of the climate and architecture of the brick, desert areas and other attractions related to the qanat for sustainable development of the tourist canoes

- More efforts are being made to make effective decisions to identify the native culture of Yazd to tourists

- Returning the management of the qanats of Yazd to the indigenous people and directing the development of the city along the qanats for its sustainability

- Introduction of qanat technology to tourists in the form of advertising and virtual networks.

Table 9. SWOT/TOWS Matrix

\begin{tabular}{|c|c|c|}
\hline & Strenghts & Weaknesses \\
\hline Opportunities & $\begin{array}{c}\text { S-O } \\
\text { strategies }\end{array}$ & $\begin{array}{c}\text { W-O } \\
\text { strategies }\end{array}$ \\
\hline Threats & $\begin{array}{c}\text { S-T } \\
\text { strategies }\end{array}$ & $\begin{array}{c}\text { W-T } \\
\text { strategies }\end{array}$ \\
\hline
\end{tabular}

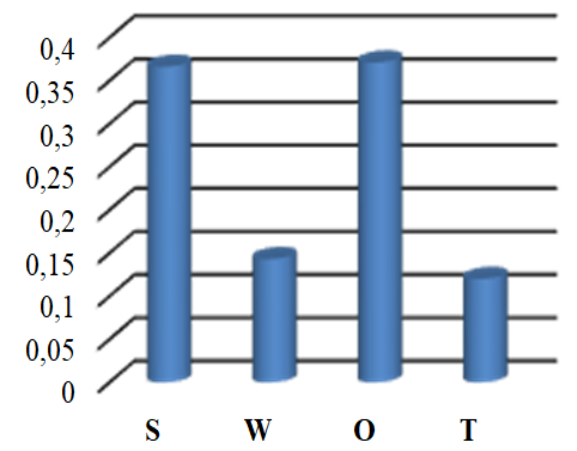

Figure 7. Prioritizing Fourth SWOT Factors

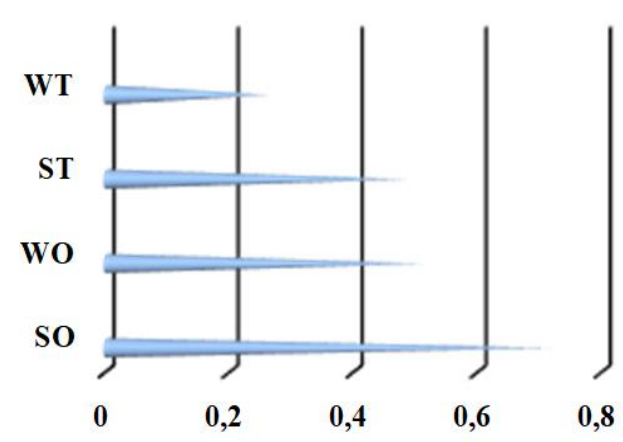

Figure 8. Prioritizing the strategies of development of qanat tourism in Yazd

\section{CONCLUSION}

Sustainable tourism is the concept of visiting a place as a tourist and trying to make a positive impact on the environment, society, and economy. There is now broad consensus that tourism development should be sustainable; however, the question of how to achieve this remains an object of debate. Since in the sustainable tourism approach, attention to local capacities is a priority, there is also an element such as qanat with a long history in the historical city of Yazd, which in the past has had many functions in the field of water supply in desert areas.

Due to the lack of proper use of this structure and its abundant capabilities, it seems that the subject of qanat tourism and the enjoyment of its technology, structure, beauty and natural and geological attraction can make it more sustainable. A lot of studies have been done on the Qanat and its functions include, Mehrvaran (2005), Sadeghirad (2005), Nasiriyen (2006), Mustafa and Usman (2007), Hussain et al. (2008), Laghaei et al. (2012), Abbasnejad et al. (2016), Parise (2016), Goes (2017), but the distinction between the research and the similar research is the attention to the qanat tourism aspect and the combination of the two SWOT and AHP models for the presentation of the strategy.

According to the use of the AHP model and experts' opinions, the results indicate that the strengths and opportunities in the field of qanat tourism in Yazd have been more important. Also, SO and WO strategies are the first priorities. As a result, the main strategies to create sustainable tourism in various dimensions of economic, social, cultural for the development and rehabilitation of the qanat for tourism can include investment, appropriate advertising, the creation of more tourist facilities and the use of indigenous people living in the vicinity of the qanats of Yazd city. As a result, it can be said that qanat is a cultural element for the historic city of Yazd, which can be effective in boosting tourism in this city.

Indeed, this issue is still at the forefront and it is associated with cultural, historical, social and natural topics. While natural crises such as drought and dehydration are related to the qanat, the topic of restoring qanats can be effective in countering these problems. It is said that qanat tourism can increase the attention of individuals to this civilization structure, and this also plays an important role in the reconstruction of it. It seems that future research should focus on the use of modern techniques and technology for utilizing the opportunities of the qanat and somehow the principles of the past have been updated and appropriate measures are being taken to further maintain the stability of the dry areas in order to further harmonize with the climate.

\section{REFERENCES}

Abbasnejad, A., Abbasnejad, B., Derakhshani, R., \& Hemmati Sarapardeh, A. (2016). Qanat hazard in Iranian urban areas: explanation and remedies. Environmental Earth Sciences, 75(19), 1306. https://doi.org/10.1007/s12665-016-6067-6

Baali, E., Azouggagh, M., \& Ahlrchid, O. (2002). Water pumping for irrigation in Southern Moroccan Oasis. International Research on food security natural resource Management and rural development, Kassal - Witzenhausen, 9-11. https://www.tropentag.de/2002/abstracts/full/109.pdf

Bimonte, S., \& Punzo, L. (2003). Turismo, sviluppo economico e sostenibilita': Teoria e pratica. [Tourism, economic development: Theory and practice economica și sustenabilitate: Teorie și practica]. Siena, Protagon, 1-7, (in Italian).

Bonine, M.E. (1979). The Morphogenesis of Iranian Cities. Annals of the Association of American Geography, 69(2), 208-224. https://doi.org/10.1111/j.1467-8306.1979.tb01252.x

Carrión, A., \& Fornes, A. (2016). Underground medieval water distribution network in a Spanish town. Tunneling and Underground Space Technology, 51, 77-90. https://doi.org/10.1016/j.tust.2015.10.015

Crossley, J., Jamieson, L., \& Brayley, R. (2012). Introduction to commercial recreation and tourism: An entrepreneurial approach (6th ed). Sagamore Publishing. 
English, P.W. (1968). The Origin and Spread of Qanats in the Old World. American Philosophical Society, 112(3), 170-181. https://www.jstor.org/stable/986162

Ghanian, M., Ghoochani, O.M., \& Crotts, J.C. (2014). An application of European Performance Satisfaction Index towards rural tourism: The case of western Iran. Tourism Management Perspectives, 11 (2014), 77-82. https://doi.org/10.1016/j.tmp.2014.04.005

Goblot, H. (1979). Qanats: a technique acquisition of water, Paris, Mouton. https://www.researchgate.net/publication/268035049

Goes, B.J.M., Parajuli, U.N., Haq, M., \& Wardlaw, R.B. (2017). Karez (qanat) irrigation in the Helmand River Basin, Afghanistan: a vanishing indigenous legacy. Hydrogeology Journal. 25(2), 269-86. https://doi.org/10.1007/s10040-016-1490-z

Gorener, A., Toker, K., \& Ulucay, K. (2012). Application of Combined SWOT and AHP: A case study for a Manufacturing Firm. ProcediaSocial and Behavioral Sciences, 58 (2012), 1525-1534. https://doi.org/10.1016/j.sbspro.2012.09.1139

Gravili, S., Iazzi, A., \& Rosato, P. (2015). Competitive Processes in Tourism Destinations: The Role of Intangible Assets, International Journal of Management Cases, 14, 3. https://www.researchgate.net/publication/27641063

Hashemi, N., \& Ghaffary, G. (2017). A Proposed Sustainable Rural Development Index (SRDI): Lessons from Hajij village, Iran. Tourism Management, 59 (2017), 130-138. https://doi.org/10.1016/j.tourman.2016.07.021

Hussain, I., Abu Rizaia, S.O., Habib Mohamed, A.A., \& Ashfaq, M. (2008). Revitalizing a traditional dryland water supply system, the karezes in Afghanistan, Iran, Pakistan the Kingdom of Saudi Arabia. Water International, 33(3), 333-349. https://doi.org/10.1080/02508060802255890

Joseph, E.K., Kallarakal, T.K., Varghese, B., \& Antony. J.K. (2020). Sustainable Tourism Development in the Backwaters of South Kerala, India: The Local Government Perspective. GeoJournal of Tourism and Geosites, 33(4spl), 1532-1537. https://doi.org/10.30892/gtg.334spl13-604

Kahraman, C., Demirel, N.C., \& Ates, N.Y. (2008). A SWOT-AHP application using fuzzy concept: E- Government in Turkey, Fuzzy MultiCriteria Decision Making Book, Edited by Cengiz Kahraman, Springer Science- Business Media, 47-50.

Ko, T.G. (2005). Development of a tourism sustainability assessment procedure: A conceptual approach. Tourism Management, 26, 431-445. https://doi.org/10.1016/j.tourman.2003.12.003

Laghaei, H.A., Atabi, F., \& Farjam, Z. (2012). Strategic Management and Planning to Use QAanat's Potentials in Cities (Case Study: Sanglag Qanat in Tehran). Iranian Water Research Journal, 6(10), 131-144, (in Persian). https://journal.sku.ac.ir/IWRJ/Paper/1777

Makiyan, S.N., \& Naderi, B. (2003). Study of foreign tourism in Yazd city. Journal of Economic Research, 38(1), 195-205, (in Persian). https://jte.ut.ac.ir/article_10007.html?lang=en

Mehrvaran, F. (2005). Investigating the effects of development on quantity and Quality of Qannat Water: The Qanats of Koosk Bibiche located northeast of Shiraz city. Shiraz University, Shiraz, Iran, (in Persian).

Morar, C., Grama, V., Stupariu, M.I., Nagy, G., Boros, L., Tiba, A., Gozner, M., \& Szabo-Alexi, M. (2020). Local Perspectives over Cultural Tourism to Heritage Sites. The Case Study of Oradea Fortress (Romania). GeoJournal of Tourism and Geosites, 33(4spl), $1470-1479$. https://doi.org/10.30892/gtg.334spl04-595

Mustafa, D., \& Usman, M. (2007). Transition from Karez to Tubewell Irrigation: Development, Modernization, and Social Capital in Balochistan, Pakistan. World Development, 35(10), 1796-1813. https://doi.org/10.1016/j.worlddev.2007.06.002

Nasiriyen, N. (2006). Examining the Factors Affecting the Sustainable Development of Qanat-based Irrigation System in the Cities of Garmsar and Semnan with emphasis on the role of agricultural extension. Thesis Master of Agricultural Engineering.Agricultural extension and training. Islamic Azad university, Iran, (in Persian).

Othman, P., \& Rosli, M.M. (2011). The impact of tourism on small business performance: Empirical evidence from Malaysian islands. International Journal of Business and Social Science, 2(1), 11-21. https://doi.org/10.30845/ijbss

Papoli Yazdi, M.H., \& Labbaf Khaneiki, M. (2000). The role of qanat in the formation of civilizations: The theory of the sustainability of culture and civilization. Proceedings of Qanat, Vol. I, Yazd Regional Water Company, (in Persian).

Parise, M. (2016). Qanat is not a hazard. Environmental Earth Sciences. 75(23), 1476. https://doi.org/10.1007/s12665-017-6526-8

Pineda, F.D., \& Brebbia, C.A. (2012). Sustainable tourism V. WIT Press, UK.

Quebec Declaration on Ecotourism. (2002). Québec City, Canada, 22 May 2002.

Rathore, N. (2012). Rural tourism impact: Challenges and opportunities. International Journal of Business Economics and Management Research, 2(2), 252-260. https://www.researchgate.net/publication/266054088

Remini, B., Kechad, R., \& Achour, B. (2014). The Collecting of Groundwater by the Qanats: A Millennium Technique Decaying. Larissa Journal, 20 (1), 259-277. http://larhyss.net/ojs/index.php/larhyss/article/view/246

Rowe, G., \& Wright, G. (1999). The Delphi technique as a forecasting tool: issues and analysis. International Journal of Forecasting, 15 (4), 353-375. http://www.sciencedirect.com/science/article/pii/S0169-2070(99)00018-7

Sadeghirad, M. (2005). Application of the Madflow model in assessing the use of the qanat system to lower the groundwater level in Shiraz plain. Master Dissertation of Civil Engineering. Shiraz University, Shiraz, Iran, (in Persian).

Safarabadi, A., Moayedfar, S., \& Varesi, H. (2015). Urban sustainable development with emphasis on the empowerment of informal settlements in urban areas. The case of Yazd, Iran. European Journal of Geography, 6(1), 83-97. http://www.eurogeographyjournal.eu/showPaper.php?id=562

Semsar Yazdi, A.A., \& Labbaf Khaneiki, M. (2014). Qanats of Iran and Yazd at a Glance. Booklet of "Reuse Recycle Yazd" A workshop on qanats and architecture, Yazd, Iran, (in Persian).

Sharma, M.J., Moon, I., \& Bae, H. (2008). Analytic hierarchy process to assess and optimize distribution network. Applied Mathematics and Computation, 202 (1), 256-265. https://doi.org/10.1016/j.amc.2008.02.008

Vaughan, C.S. (2021). Qanat definition. World History Encyclopedia. https://www.ancient.eu/qanat

Waridin, \& Astawa, I.P. (2021). Shifting of Land Use in Sustainable Tourism: A Local Cultutal Approach in Indonesia. GeoJournal of Tourism and Geosites, 35(2), 270-274. https://doi.org/10.30892/gtg.35201-647

Wilson, A. (2008). Hydraulic Engineering and Water Supply. The Oxford Handbook of Engineering and Technology in the Classical World. Edited by John Peter Oleson, 290-293. https://doi.org/10.1093/oxfordhb/9780199734856.013.0012

Yuksel, J., \& Dagdeviren, M. (2007). Using the analytic network process (ANP) in a SWOT analysis - A case study for a textile firm. Information Sciences, 177, 3364-3382. https://doi.org/10.1016/j.ins.2007.01.001

*** WTO-UNEP. (2002). Que'bec declaration on ecotourism. Québec City, Canada, 22 May 2002.

Article history: Received: 12.01.2021 Revised: 06.03.2021 Accepted: 29.04.2021 Available online: 24.05.2021

